Jürgen Brokoff (1968-) forsøgt at gøre i monografien "Die Apokalypse in der Weimarer Republik" fra 2001, hvor Brokoff gør direkte brug af Derridas definitionsramme i defineringen af Carl Schmitts, Walter Benjamins, Ernst Jüngers og Adolf Hitlers tekster som apokalyptiske.

Derridas definition på apokalypse og apokalyptisk udmærker sig ved den sproghandlingsteoretiske ramme. De mere traditionelle og skoledannende definitioner på begreberne inkluderer nemlig ikke dette sproghandlingsteoretiske aspekt.

Pbilip Martinusen

\section{Til Holbergs kend- og kundskab}

Eiliv Vinje \& Jorgen Magnus Sejersted (red.): Ludvig Holbergs naturrett, Gyldendal Akademisk (Norge), 2012, 256 sider, 398 NOK.

Ludvig Holberg (1684-1754) er for mange bedst kendt for sine komedier, som Den Politiske Kandestaber (1722), Jeppe på Bjerget (1722) og Erasmus Montanus (1723), samt ikke mindst rejseromanen Niels Klims underjordi- ske Rejse (1741), der bredt regnes for at være den første egentlige roman i den dansk-norske litteraturhistorie. Holbergs forfatterskab spænder imidlertid over langt mere end 'blot' hans skønlitterære værker. Bag sig havde Holberg således en anseelig produktion af filosofiske, juridiske og historiske værker. Et af de mest kendte af disse er, foruden storværket Dannemarks Riges Historie (1732-35), hans juridisk-filosofiske værk Morals Kierne eller Introduction til Naturens og Folke-Rettens Kundskab, der blev udgivet første gang i 1716 samt genudgivet hele fem gange i perioden 1728 til 1763.

Det er netop Holbergs naturret, der er i fokus for den norske gren af Gyldendals nye antologi Ludvig Holbergs Naturrett. Antologien består af i alt 13 bidrag, der alle er udarbejdet på baggrund af et seminar ved Universitetet i Bergen i 2011, hvor også begge antologiens redaktører, Eiliv Vinje og Jørgen Magnus Sejersted, er tilknyttet. Bidragsyderne består af både norske, svenske og danske Holberg-forskere fra så forskellige discipliner som jura, litteratur, idéhistorie og historie. Der må således siges at være tale om et både fællesnordisk og særdeles 
tværfagligt projekt.

Natur- og Folkeretten var allerede i Holbergs samtid et vigtigt og indflydelsesrigt værk, hvilket de mange genudgivelser også vidner om. Det var første gang, at naturretten, der i det $17 . \mathrm{og}$ 18. århundrede gennemløb en blomstringstid i Europa, blev formidlet til et dansk publikum på dansk (og ikke latin, som man ellers kunne forvente). Holbergs værk var selvfølgelig hans egen fortolkning af naturretten, men stod ikke desto mindre i stor gæld til naturretstraditionens centrale skikkelser som Hugo Grotius (1583-1654), Thomas Hobbes (1588-1679), Samuel Pufendorf (1632-94) og Christian Thomasius (16551728). Særligt Pufendorf var en kraftig kilde til inspiration - på grænsen til det plagierende ville nogle mene. Holbergs ærinde var, selvom naturretten havde rødder helt tilbage i antikken, at formidle datidens aktuelle, europæiske nyudvikling af naturretten videre til sine landsmænd - nærmere bestemt til brug ved Det Juridiske Fakultet på Københavns Universitet. Hvad værket måske kunne siges at mangle $\mathrm{i}$ originalitet, giorde det op for $\mathrm{i}$ indflydelse og grundarbejde.
Den generelle tilgang i antologien til Holbergs naturret er, som det allerede markeres $i$ indledningen (s.10), at undersøge Holberg ud fra et historiserende perspektiv, hvormed der menes at fremhæve hans tilknytning til den naturretstænkning der florede i Europa i hans samtid. Til dette har hver bidragsyder leveret hvert deres perspektiv og både disciplinære og emnemæssige tilgang.

Nogle af bidragsyderne har således valgt at anlægge et bredt perspektiv, som bl.a. Knud Haakonssens (University of Sussex) bidrag, der giver en bred idéhistorisk gennemgang af naturretstænkningen på Holbergs tid, og medredaktør Eiliv Vinje, der undersøger forholdet til naturretten i Holbergs samlede forfatterskab. Andre bidragsydere har omvendt valgt at undersøge mere specifikke tematikker, såsom Eirik Holmmøyvik (Universitetet i Bergen), der undersøger Holbergs forhold til og ikke mindst forsvar af enevælden, der dannede en rød tråd gennem hele hans forfatterskab, eller Kristoffer Schmidt (ph.d.-stud., SAXO-instituttet, $\mathrm{KU})$ der undersøger Holbergs kritik af den spanske kolonisering af Amerika, eller med et 
helt andet perspektiv Gina Dahl (post.doc., Universitet i Bergen), der undersøger værkets bog- og receptionshistorie.

Noget af det der gør Holberg særligt interessant er, som også Sebastian Olden-Jørgensen (SAXO-instituttet, KU) fremhæver i sit bidrag, at han undersøgte og forholdte sig til naturretten filosofisk, som enhver god, dannet intellektuel ville det på den tid, samtidig med at han skrev sig ind i en dansk-norsk historisk kontekst. Det er især dette forhold, der gør ham så interessant $\mathrm{i}$ den dansk-norske idéhistorie. Holberg udgav endvidere Natur- og Folkeretten for han begyndte at udgive sine første komedier, og som Eiliv Vinje demonstrerer, er Holbergs forhold til naturretten vigtig at have in mente, hvis man vil forstå hans øvrige forfatterskab. Desværre er Natur- og Folkeretten et ofte negligeret værk i Holbergs forfatterskab, hvilket dog høj grad understreger relevansen af at udgive en antologi dedikeret til netop dette værk.

Der er generelt tale om en vellykket antologi, med adskillige interessante, oplysende og ikke mindst velskrevne bidrag. Skulle man udsætte noget på antologien, så er det at der mere er tale om en samling af interessante artikler end egentligt sammenhængende kapitler. Det er med andre ord ret tydeligt, at antologien har en baggrund i et afholdt seminar. Kun få gange finder man krydsreferencer mellem bidragene, der endvidere har en del emnemæssige overlap og gentagelser - f.eks. behandler næsten alle kapitler Holbergs forhold til Pufendorf, hvilket i længden føles ret repetitivt for læseren. Dette betyder dog ikke, at der ikke er tale om et grundigt og gedigent stykke akademisk arbejde - tværtimod.

Ludvig Holbergs Naturrett henvender sig til enhver med interesse for dansk idé- eller litteraturhistorie samt ikke mindst den europæiske naturretstænkning i det 17. og 18. århundrede, hvortil antologien giver et interessant perspektiv på og overblik over den nordiske reception og udbredelse. Antologien indeholder bidrag skrevet på dansk, svensk, bokmål og endda nynorsk, men udover nynorsk, der godt kan volde lidt besvær, burde ingen af sprogene udgøre noget uoverkommeligt problem for den danske læser. Alt $i$ alt et velkomment bedrag til Holberg-forskningen.

Eva Krause Jorgensen 